\title{
Membrane Currents in Identified Lactotrophs of Rat Anterior Pituitary
}

\author{
Christopher J. Lingle, Sompong Sombati, ${ }^{1}$ and Marc E. Freeman \\ The Florida State University, Department of Biological Sciences, Tallahassee, Florida 32306
}

\begin{abstract}
Qualitative features of the primary inward and outward current components of identified lactotrophs of the rat anterior pituitary were examined. Identification of lactotrophs in heterogeneous dissociated anterior pituitary cultures was accomplished by application of the reverse hemolytic plaque assay. Currents in lactotrophs were subsequently examined using whole-cell or patch recording techniques.
\end{abstract}

Two components of inward calcium current were observed: a transient component and a sustained component. The transient component activated at voltages as negative as $-\mathbf{5 0} \mathrm{mV}$ and was the major contributor to total lactotroph calcium current. The sustained component activated at voltages above about $-10 \mathrm{mV}$. The 2 currents could be qualitatively separated by differences in inactivation properties and in sensitivity to cadmium.

At least 3 components of outward current were distinguished. Either $30 \mathrm{~mm}$ TE $\Lambda$ or 0 calcium eliminated a major portion of sustained outward current. This is likely to represent primarily calcium- and voltage-activated potassium current. The remaining current could be further differentiated into a transient current component that could be inactivated with conditioning potentials above $-60 \mathrm{mV}$. A slowly activating and deactivating potassium current remained following inactivation of the transient current. Although the time course of the transient current is reminiscent of " $A$ " current, activation of this current required potentials above $-30 \mathrm{mV}$. Candidates for the singlechannel currents that underlie the whole-cell outward currents were observed in cell-attached recordings.

When combined with patch-clamp electrophysiological methods, the reverse hemolytic plaque assay promises to be a powerful technique for the electrophysiological characterization of specific cell subtypes in heterogeneous dissociated cell populations.

Dissociated primary cell cultures are standard tools for the electrophysiological investigation of cellular excitability. Unfortunately, the rich heterogeneity in cell types found in many neuronal and endocrine structures frequently precludes unambiguous detection and characterization of specific cell subtypes. In the case of the anterior pituitary, electrophysiological studies of the control of hormone secretion have in general depended on the availability of clonal cell lines derived from pituitary tumors (Adler et al., 1983; Armstrong and Matteson, 1985; Biales et al., 1977; Dubinsky and Oxford, 1984; Dufy and Barker, 1982; Hagiwara and Ohmori, 1982; Kidokoro, 1975; Matteson and Armstrong, 1984) or on certain species with regions of pituitaries

\footnotetext{
Received Nov. 25, 1985; revised Mar. 20, 1986; accepted Apr. 17, 1986.

This work was supported in part by NS-19139 (C.J.L.) and HD-11669 (M.E.F.) C.J.L. is the recipient of a Research Career Development Award. We thank J. D. Neill for the generous gift of prolactin antisera, M. Truman for cell dissociations, and $\mathrm{E}$. Marder for consultation on the immunocytochemistry.

Correspondence should be addressed to Christopher J. Lingle at the above address.

1 Present address: Department of Biology, The University of Oregon, Eugene, OR 97403

Copyright $(1986$ Society for Neuroscience $0270-6474 / 86 / 102995-11 \$ 02.00 / 0$
}

enriched in particular cell subtypes (Mason and Waring, 1985; Taraskevitch and Douglas, 1978). As a result, our understanding of the electrophysiological properties of specific cell subtypes from the anterior pituitary of normal animals is limited. Recently, 2 approaches toward identification of specific cell subtypes in dispersed heterogeneous anterior pituitary populations have been developed: (1) differential gradient cell separation (Denef et al., 1978), and (2) the reverse hemolytic plaque assay (Neill and Frawley, 1983). Whereas the former provides a partial enrichment of specific cell subtypes, the latter appears to provide an unambiguous means of identification of specific cell subtypes within the heterogeneous primary cultures.

As a prelude to the analysis of electrophysiological events underlying hormone release in specific anterior pituitary cell subtypes, here we describe the application of the reverse hemolytic plaque assay for subsequent use with standard wholecell and patch-clamp electrophysiological methods. The major intent of this paper is 2-fold: first, to demonstrate that the plaque assay can be used in conjunction with electrophysiological methods and, second, to describe the basic qualitative features of some of the ionic currents found in these cells.

The mechanisms of control of prolactin release from the rat anterior pituitary are of particular interest since lactotrophs are subject to a rich variety of releasing factors, both stimulatory and inhibitory in nature (Leong et al., 1983). Additionally, estradiol influences the ability of the lactotroph to respond to these other agents. The secretory capacity of the lactotroph even in dissociated cell culture is also subject to previous physiological states of the animal, including the estrous cycle, pregnancy, and lactation. As a result, in order to define a baseline of lactotroph function, we chose to perform the initial experiments described here on lactotrophs from pituitaries isolated from long-term ovariectomized rats. We find that identified lactotrophs exhibit at least 2 different components of calcium current and at least 3 components of potassium current. Preliminary accounts of this work have been presented in abstracts (Lingle et al., 1985a, b).

\section{Materials and Methods}

\section{Pituitary gland dissociation and cell culture}

We have used the collagenase/hyaluronidase method of Vale and colleagues (1972) to dissociate anterior pituitary glands obtained from ovariectomized rats by rapid decapitation. Our use of this method for dissociation and culturing of cells for studies of hormone secretion has been published previously (Gorospe and Freeman, 1984). The cells were either used immediately or placed in $35 \mathrm{~mm}$ tissue culture dishes (1$1.5 \times 10^{6}$ cells $/ 2 \mathrm{ml}$ Dulbecco's Modified Eagle's Medium containing $10 \%$ horse and $5 \%$ rat serum (DMES)/dish) and incubated in a watersaturated atmosphere of $95 \%$ air, $5 \% \mathrm{CO}_{2}$ until used in the reverse hemolytic plaque reaction. One to 7 days after initiation of the cultures, cells were removed from the dishes by substitution of the DMES with Spinner's medium at $37^{\circ} \mathrm{C}$ containing $0.025 \%$ trypsin. With constant aspiration of the media, greater than $90 \%$ of the adherent pituitary cells could be dislodged within $15 \mathrm{~min}$. Cells were then washed 3 times in Dulbecco's Modified Eagle's Medium containing 0.1\% BSA (DMEM$0.1 \% \mathrm{BSA}$ ) prior to performance of the reverse hemolytic plaque re- 
action. All sera used in media were filtered with charcoal to remove steroids.

\section{Reverse hemolytic plaque reaction}

Ovine erythrocytes (Colorado Serum Company, Denver) were coupled covalently with staphylococcal protein A (Sigma Chemical Company) using an aged solution of chromium chloride hexahydrate $(0.1 \mathrm{mg} / \mathrm{ml}$ saline) that had been stored in the dark. A $1 \mathrm{ml}$ aliquot of packed red cell volume was washed 3 times by resuspension in saline and centrifugation. Then, $1 \mathrm{ml}$ protein A $(0.5 \mathrm{mg} / \mathrm{ml}$ saline $)$ and $10 \mathrm{ml}$ of the chromium chloride solution were used to resuspend the washed erythrocytes. After mixing, the cells were incubated at $30^{\circ} \mathrm{C}$ for $1 \mathrm{hr}$, washed twice with saline, twice with DMEM-0.1\% BSA, resuspended, and stored as a $2 \%$ solution $(\mathrm{vol} / \mathrm{vol})$ in $50 \mathrm{ml} \mathrm{DMEM}-0.1 \% \mathrm{BSA}$.

The reverse hemolytic plaque reaction was performed by a modification of that described by Neill and Frawley (1983). Cunningham chambers were constructed by placing 2 strips of Scotch Double Stick Tape $20 \mathrm{~mm}$ apart across a clean glass slide (Cunningham and Szenberg, 1968). A poly(L-lysine)-coated square $22 \mathrm{~mm}$ coverslip was gently lowered onto the 2 pieces of tape. Equal volumes of $3 \times 10^{6}$ monodispersed pituitary cells and a $12 \%$ suspension of the protein A-coated ovine erythrocytes were mixed and infused by capillarity under the poly(Llysine)-coated coverslip. The slide was immediately inverted and rested on a $60 \mathrm{~mm}$ culture dish within a $100 \mathrm{~mm}$ culture dish and placed in the $\mathrm{CO}$, incubator for $45 \mathrm{~min}$. With this procedure, the cells sink and subsequently adhere to the poly(L-lysine)-coated coverslip and not to the slide. After incubation, slide chambers were righted and nonadherent red cells and pituitary cells were removed by drawing fresh DMEM$0.1 \%$ BSA through the chambers with adsorbent tissue. The chambers were then filled by a similar procedure with a solution of prolactin antiserum (designated JDN-pool), diluted 1:40 in DMEM-0.1\% BSA and replaced in the $\mathrm{CO}_{2}$ incubator for $45 \mathrm{~min}$. After this time, the antiserum was rinsed from the chamber with DMEM-0.1\% BSA and replaced with guinea pig serum (GIBCO diluted 1:100) as a source of complement. Regions of hemolysis surrounding pituitary cells were observed within 10-30 min, and the reaction was terminated by rinsing the guinea pig serum from the chambers with fresh DMEM-0.1\% BSA. The coverslips were then gently slid off the double stock tape and placed, with the adherent cells exposed, in a $35 \mathrm{~mm}$ culture dish. The dish was flooded with DMEM-0.1\% BSA and stored in the incubator for $1-8 \mathrm{hr}$ until used for electrophysiological studies.

\section{Immunocytochemistry}

Immunocytochemistry was performed to verify that the anterior pituitary cells identified by plaque formation were indeed lactotrophs. The plaque reaction was performed and coverslips placed in $35 \mathrm{~mm}$ culture dishes with the cells exposed as described above. The prolactin antiserum was eluted from the erythrocyte-protein A conjugates by flooding the dishes for $6 \mathrm{~min}$ with cold buffer consisting of $0.2 \mathrm{M}$ sodium acetate, $0.4 \mathrm{M}$ sodium chloride adjusted to $\mathrm{pH} 2.5$. The elution buffer was then removed, and cells were rinsed in DMEM-0.1\% BSA. Cells were fixed with $4 \%$ paraformaldehyde in $0.1 \mathrm{~m}$ phosphate buffer (wt/vol), $\mathrm{pH} 7.3$, overnight at $4^{\circ} \mathrm{C}$. The following day the fixation solution was removed and the cells were washed 6 times with cold $0.1 \mathrm{M}$ phosphate buffer containing $0.1 \%$ sodium azide and $0.3 \%$ Triton X-100. The cells were then incubated overnight at $4^{\circ} \mathrm{C}$ with a different prolactin antiserum (designated JDN-10) diluted 1:20,000 in the phosphate, azide, Triton buffer. The specificity of this antiserum for prolactin has been previously demonstrated (Neill and Reichert, 1971). The following morning, the dishes were again washed in phosphate, azide, Triton buffer ( 6 times, $4^{\circ} \mathrm{C}$ ). Swine anti-goat IgG-conjugated to fluorescein isothiocyanatc (FITC) was diluted 1:20 with buffer, added to the cells, and allowed to incubate at $4^{\circ} \mathrm{C}$ overnight. The following morning the anti-goat IgG-FITC was removed and the cells were washed 6 times with cold buffer and once with $4 \mathrm{~mm}$ sodium carbonate, $\mathrm{pH} 9.5$, to enhance fluorescence. The coverslips were removed from the dishes and placed on a slide with mounting medium consisting of $90 \%$ glycerol, $10 \% \mathrm{PBS}, \mathrm{pH} 9.0$, and $100 \mathrm{mg} / \mathrm{ml}$ DABCO (Aldrich). The latter compound, DABCO $(1,4-$ diazabicyclo[2.2.2]-octane), is an antioxidant used to prevent fluorescence fading. Cell lawns were scanned for the proportion of plaqueforming cells that fluoresced in response to sequential treatment with prolactin antiserum and anti-goat IgG-FITC. Representative examples were photographed with fluorescence microscopy in addition to phasecontrast or Nomarski optics.

\section{Electrophysiological experiments}

In preparation for patch-clamp recording, medium was gradually replaced with a saline containing $130 \mathrm{~mm} \mathrm{NaCl}, 2 \mathrm{mM} \mathrm{KCl}, 5.4 \mathrm{~mm}$ $\mathrm{MgCl}_{2}, 1.6 \mathrm{mM} \mathrm{CaCl}_{2}, 10 \mathrm{~mm}$ NaHEPES, pH 7.4, and subsequently transferred to $35 \mathrm{~mm}$ culture dishes. The whole-cell patch-clamp technique was used to voltage-clamp the cells, and single channels were examined using either cell-attached or excised patch-clamp methods (Hamill et al., 1981). For whole-cell recordings, the clamp amplifier (Dagan model 8900 ) was used with a $1 \mathrm{G} \Omega$ headstage. Series resistance was not compensated. Since the cell input resistances were in the range of 2-8 G , lack of series resistance compensation introduces negligible errors in the estimates of membrane potentials. Seal resistances ranged from 4 to $10 \mathrm{G} \Omega$ with borosilicate glass and $>10 \mathrm{G} \Omega$ with aluminosilicate glass. Only the latter were used for whole-cell recordings. Unless otherwise indicated, solutions used to examine whole-cell outward currents were as follows: pipette solution - $130 \mathrm{~mm} \mathrm{KCl,} 10 \mathrm{~mm}$ EGTA, $2 \mathrm{~mm}$ $\mathrm{MgCl}_{2}$, and $10 \mathrm{mM}$ KHEPES, pH 7.3; bath solution-130 $\mathrm{mm} \mathrm{NaCl}, 2$ $\mathrm{mM} \mathrm{KCl}, 1.6 \mathrm{mM} \mathrm{CaCl}_{2}, 5.4 \mathrm{~mm} \mathrm{MgCl}_{2}$, and $10 \mathrm{~mm}$ NaHEPES, pH 7.4. Solutions used for whole-cell inward currents were the following: pipette solution - $130 \mathrm{~mm} \mathrm{CsCl,} 10 \mathrm{~mm}$ NaHEPES, $10 \mathrm{~mm}$ EGTA, pH 7.4; bath solution - $140 \mathrm{~mm}$ TRIS chloride; $10 \mathrm{mM} \mathrm{CaCl}_{2}, \mathrm{pH} \mathrm{7.2.} \mathrm{For}$ single-channel recordings of calcium-activated potassium channels, the calcium concentration was buffered using the recipes of Wong et al. (1982).

The procedures for initiating seal formation and the whole-cell recording configuration were as follows. With the pipette in the bath, the junction potential between the pipette solution and the bath was zeroed such that no current flowed through the bath-electrode system. Gigohm seals were then formed with the pipette clamped to this junction potential. Application of additional suction following formation of the cell-attached patch led to patch rupture and initiated dialysis of the cell with the contents of the pipette. Over the next $10-30 \mathrm{sec}$, a DC potential was then applied until net membrane currents were readjusted to zcro. It is likely that the ionic composition of the cell is primarily determined by the pipette solution within this time (Fenwick et al., 1982; Matteson and Armstrong, 1984). The applied potential relative to the bath potential was defined as the cell resting potential. Cells were then maintained at holding potentials of -60 or $-80 \mathrm{mV}$ prior to initiation of voltage-jump protocols. Cell membrane resistance was estimated using the steady-state response to hyperpolarizing voltage commands from a holding potential of $-60 \mathrm{mV}$. No indication of voltage- or time-dependent conductances was observed at potentials more negative than $-60 \mathrm{mV}$. Values of membrane resistances are uncorrected for the parallel resistance resulting from the cell membrane-pipette shunt. Our values for membrane resistance are therefore underestimates. Although estimates of the shunt resistance following patch rupture are uncertain, assuming that the shunt resistance is identical to the resistance $(>10$ $\mathrm{G} \Omega$ ) measured in the cell-attached recording mode prior to rupture of the patch, in a typical case resistances would be underestimated by about $20 \%$.

With the salines used in these experiments, the better recordings lasted from 20-30 min. When recording inward calcium currents, it was noted that some run-down in the sustained component of calcium current occurred, while the transient component was stable. In comparisons of relative amplitude of the 2 components, currents were compared within the first $5 \mathrm{~min}$ following initiation of whole-cell recording.

Voltage commands were applied through an IBM PC-XT microcomputer using a Quatech wave generator board, and current sweeps were digitized at $5 \mathrm{kHz}$ directly onto disk using a Data Translation 2801-A board. Currents generated by hyperpolarizing voltage jumps were used for off-line digital subtraction of non-voltage-dependent leakage and capacitative currents. For detection and analysis of single ion channels, an automated software event detection and analysis routine (IPROC-2) running on IBM microcomputers was employed. For voltage-activated single-channel sweeps and ensemble averages, leakage and capacitative currents were subtracted using either the off-step of the command voltage step or a single sweep in which no detectable channels were activated. This single sweep subtraction procedure results in the addition of some noise to the single-channel sweeps.

Cells identified by the reverse hemolytic plaque assay were typically spherical, with a diameter of 10-15 $\mu \mathrm{M}$. Cells chosen for electrophysiological experiments met the following criteria: (1) No other pituitary cell was found within the area of the plaque; (2) red blood cell ghosts could be observed surrounding the pituitary cell; and (3) red blood cells 
around the plaque were sufficiently dense and uniformly distributed to preclude the occurrence of a false plaque.

\section{Results}

\section{Use of the plaque assay for identification of lactotrophs}

The hemolytic plaque assay is a method for identification of functionally discrete cell types in a mixed population of cells based on the identification of a specific secretory product of the cell type of interest (Jerne et al., 1974; Molinaro et al., 1981). This approach has been used by Neill and colleagues to identify lactotrophs (Neill and Frawley, 1983) and somatotrophs (Smith et al., 1984) within heterogeneous populations of dispersed anterior pituitary cells. Briefly, sheep red blood cells (RBCs), to which protein $A$ has been conjugated, are mixed with dispersed pituitary cells and spread in a lawn on a coverslip. With a medium containing a prolactin antibody and complement, the prolactin antibody associates with the protein $\mathrm{A}$. The binding of secreted prolactin to the antibody leads to the complementmediated lysis of RBCs. This lysis results in the appearance of "plaques" around those pituitary cells that secrete prolactin.

That plaque-forming areas are indicative of the secretion of a particular hormone from the cell subtype of interest is supported by extensive previous work (Neill and Frawley, 1983). We have also verified that, in our hands, plaques did not form when normal rabbit serum replaced the prolactin antiserum and that ${ }^{125}$ I-rat luteinizing hormone did not bind to the protein A-coated sheep erythrocytes at a dilution of the prolactin antiserum that bound $80 \%$ of added ${ }^{125}$ I-rat prolactin.

\section{Plaque-identified cells contain prolactin immunoreactivity}

In further verifying that the plaque assay can be used to identify lactotrophs unambiguously, plaque-forming cells revealed by prolactin antiserum JDN-pool (Fig. $1 A$ ) were tested for the prescnce of prolactin immunorcactivity using a different validated prolactin antiserum, JDN-10, and a fluorescein-labeled second antibody (Fig. 1B). RBC ghosts can be clearly discerned in the area of hemolysis surrounding plaque-identified pituitary cells (Fig. $1 \mathrm{~A}$ ) and intense fluorescence is associated with plaqueidentified cells (Fig. $1 B$ ). For 4 independent cultures, $100 \%$ of cells around which plaque formation was observed exhibited immunofluorescence in response to incubation with the different prolactin antisera and the FITC-labeled IgG. In contrast, fluorescence was generally not observed in association with nonplaque-forming cells, as seen in Figure $1 C$ for the same cell lawn. The presence of prolactin immunoreactivity in some nonplaque-forming cells (particularly in cultures from ovariectomized animals) suggests that basal secretion of prolactin-immunoreactive material from some cells may be insufficient to generate plaque formation. Irrespective of the basis for immunoreactive material in some non-plaque cells, since we have never observed a nonfluorescent plaque cell of over 150 plaques examined, we are confident that the plaque-identified cells can be considered to contain and secrete prolactin-like immunoreactive material.

\section{Basic properties of lactotrophs}

Resting potentials from identified lactotrophs of ovariectomized rats were $-42.8 \pm 8.35 \mathrm{mV}(\mathrm{SD} ; n=11)$ measured from the zero-current voltage following formation of a whole-cell recording using a high- $\mathrm{K}^{+}$pipette solution under voltage-clamp conditions. Cell input resistances measured over potentials from -60 to $-120 \mathrm{mV}$ were in the range of 2-8 G $\Omega$ with a mean of $5.2 \pm 2.4 \mathrm{G} \Omega(\mathrm{SD} ; n=10)$. These values are virtually identical to values found in the $\mathrm{GH} 3$ and $\mathrm{GH} 4$ clonal cell lines obtained by similar methods (Dubinsky and Oxford, 1984), which suggests that the plaque assay did not open new leakage current pathways in the lactotroph membrane. Similar to $\mathrm{GH} 4$, but not to GH3, cells (Dubinsky and Oxford, 1984), in only 1 or 2 of over 60 cells for which cell-attached recordings were formed were current waveforms characteristic of spontaneous action potentials observed.

Typical whole-cell currents observed in identified lactotrophs are shown in Figure 2 . Currents activated by relatively large depolarizing voltage commands $(-20$ to $+80 \mathrm{mV})$ are illustrated in Figure $2 A$, and currents activated by smaller depolarizing voltage commands ( -50 through $10 \mathrm{mV})$ are shown in Figure $2 B$. From a holding potential of $-60 \mathrm{mV}$, only outward components of current are observed, which are characterized by an initial transient phase with a large sustained outward current. With holding potentials of $-80 \mathrm{mV}$ and more negative, inward current can be detected following commands to relatively negative potentials of $-50 \mathrm{mV}$. With larger depolarizing commands, inward current is masked by the rapid activation of outward currents.

Even in the absence of TTX, a large rapid component of inward current was never observed. Although imprecision in the capacitative and leakage subtraction procedures may have compromised the accurate detection of currents at times less than $1 \mathrm{msec}$, sodium currents of the magnitude described in clonal pituitary cells (Dubinsky and Oxford, 1984; Fernandez et al., 1984; Matteson and Armstrong, 1984) would certainly have been observed. However, as yet we have not done experiments directly examining sodium currents in isolation of other current components.

The experiments described below attempt to qualitatively isolate some of the components of inward and outward current in the identified lactotrophs.

\section{Inward current components}

The properties of isolated calcium currents are illustrated in Figures 3 and 4. These inward currents can be considered to represent calcium currents since they were insensitive to $0.5 \mu \mathrm{M}$ TTX, were blocked by $0.5 \mathrm{~mm}$ cadmium, and were present in the complete absence of extracellular sodium. For 8 cells in extracellular saline containing $10 \mathrm{mM} \mathrm{Ca}^{2+}$, peak calcium current was $50.9 \pm 6.5 \mathrm{pA}$ (SEM). For 2 cells in $50 \mathrm{~mm}$ calcium current, mean peak current was 120.3 pA. As seen in Figure 3, calcium current could be activated at potentials as negative as $-45 \mathrm{mV}$ and exhibited a pronounced transient component at potentials more negative than $0 \mathrm{mV}$. In the 13 cells from which inward currents were examined, the peak magnitude of transient currents was in all cases similar to or greater than the peak magnitude of the sustained calcium current (e.g., Figs. 3, 4).

At more positive step potentials, a sustained or only slowly inactivating component of calcium current could be observed in some cells in addition to the transient component (Fig. 4). The variation in the relative proportion of the transient and sustained components of calcium current among different cells suggested that at least 2 separate channels were involved. This question was addressed further by 2 procedures. First, the 2 components could be separated by their different inactivation properties and, second, the 2 components exhibited a differential sensitivity to cadmium.

As seen in Figure $4 B$, depolarizing conditioning potentials of $500 \mathrm{msec}$ largely inactivate the transient component of calcium current, while the sustained component is mostly unaffected. However, it is of interest that even after $500 \mathrm{msec}$ at $-20 \mathrm{mV}$ (Fig. $4 B$, top trace), the command step to $-120 \mathrm{mV}$ results in a slow outward current, suggesting the turning off of a residual inward current. The slow time course of this outward current suggests that any residual inward current at $-20 \mathrm{mV}$ reflects a portion of the transient component that has not completely inactivated (Armstrong and Matteson, 1985) rather than the 

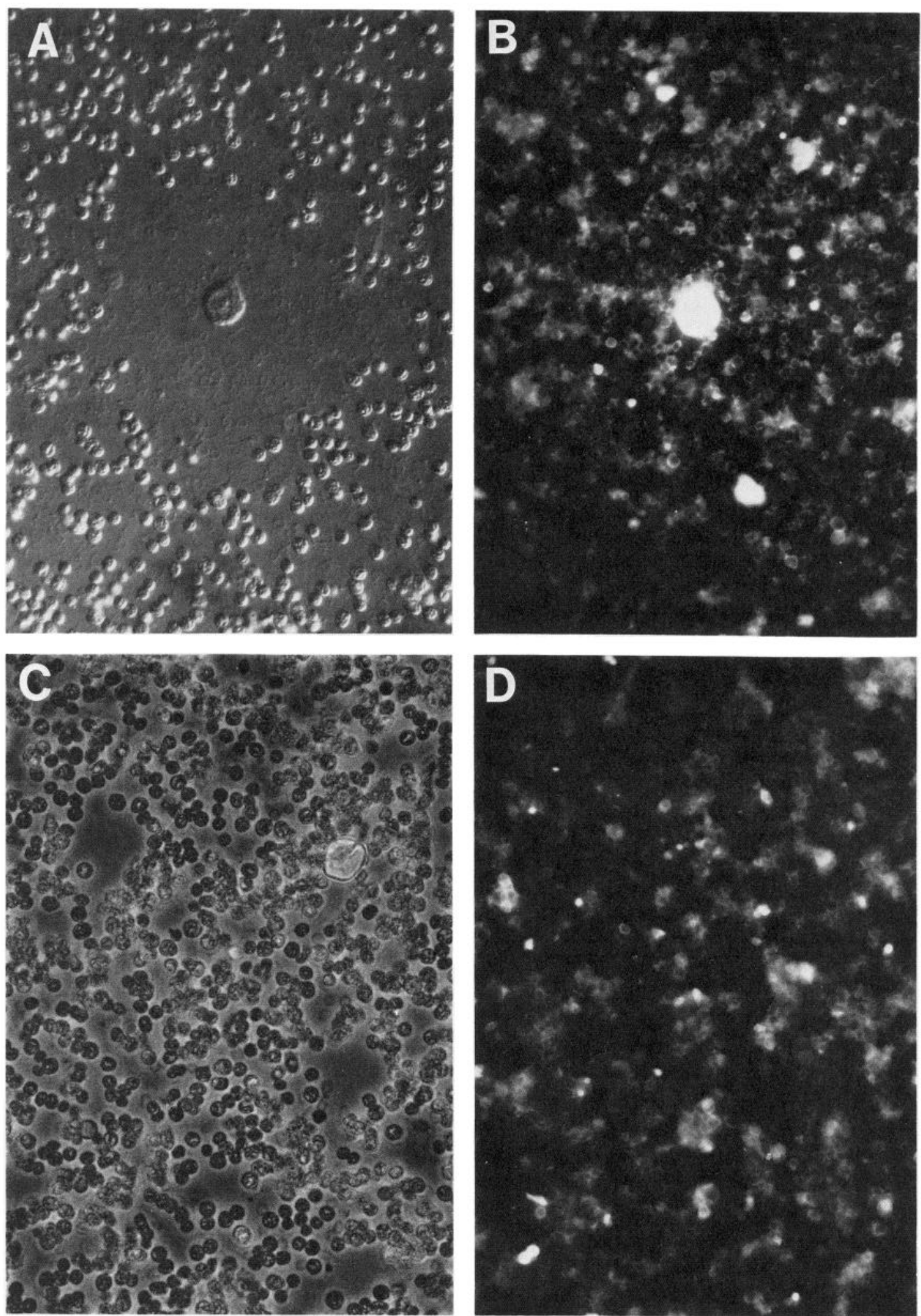

Figure 1. Demonstration of prolactin immunoreactivity in cells identified as lactotrophs by the reverse hemolytic plaque assay. $A$, Typical cell identified by the plaque assay is shown under Nomarski optics. Cell diameter is approximately $15 \mu \mathrm{m}$. Note the red blood cell ghosts in the circle of hemolysis. B, Same field, but viewed under fluorescence optics, reveals intense prolactin-immunoreactive material in association with the plaqueidentified cell. Background fluorescence diminishes with washing. $C$, Anterior pituitary cell not associated with a plaque is shown under phasecontrast optics. $D$, Under fluorescence optics, cell shown in $C$ contained no detectable prolactin-immunoreactive material. 

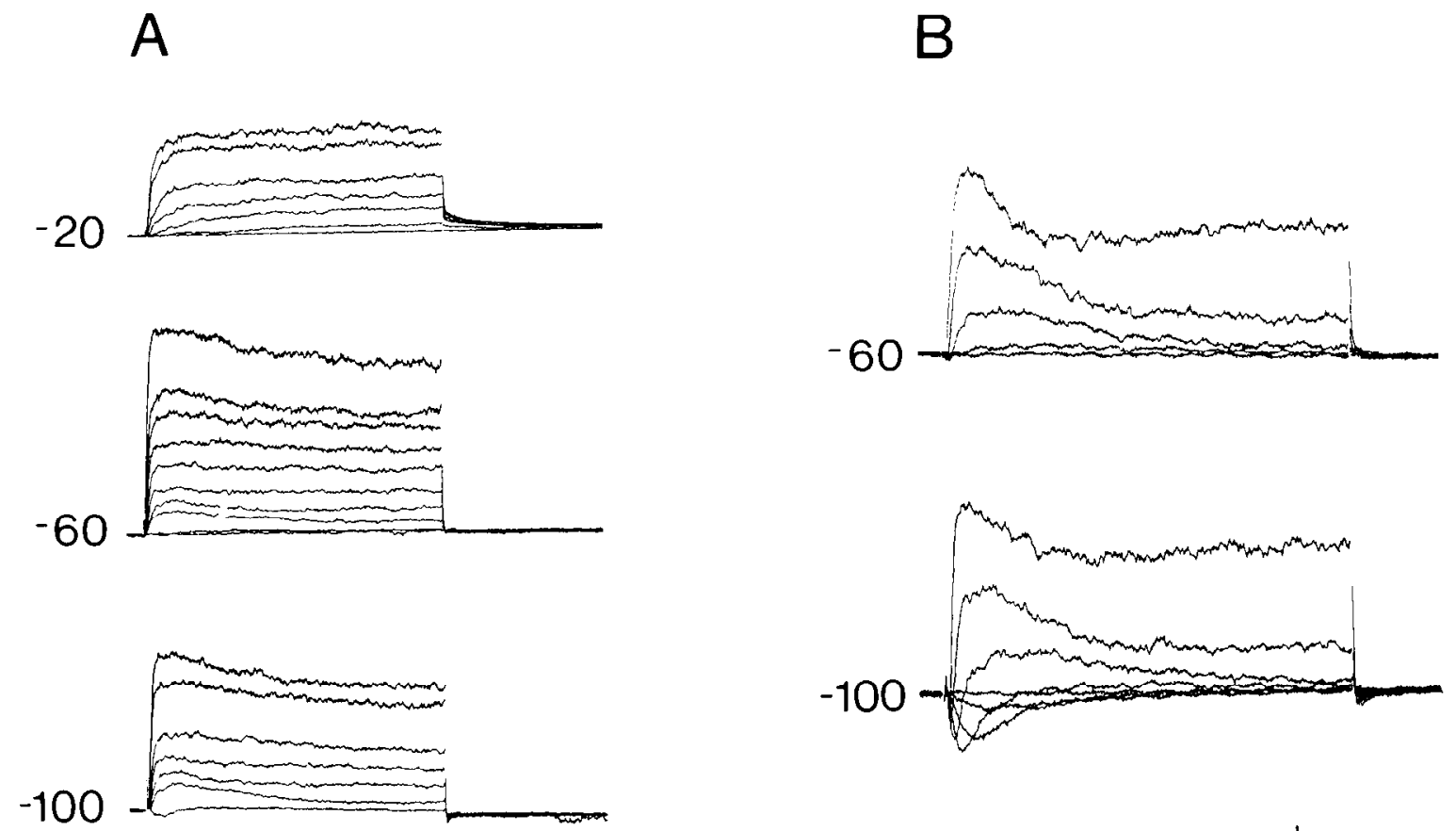

Figure 2. Typical whole-cell currents of a plaque-identified lactotroph. $A$, Traces exhibit currents activated by large depolarizing command potentials from the indicated holding potentials. Command potentials were $-120,-20$, and $0-80 \mathrm{mV}$ in steps of $10 \mathrm{mV}$. Upper left, steps to 40 and $80 \mathrm{mV}$ were omitted. $B$, Currents activated by small command potentials from the indicated holding potentials. Top, Command potentials were to -40 through $0 \mathrm{mV}$ in steps of $10 \mathrm{mV}$; hottom, command potentials were to -70 and -50 through $0 \mathrm{mV}$ in steps of $10 \mathrm{mV}$. Calibration bars: horizontal, $50 \mathrm{msec}$; vertical, $25 \mathrm{pA}$.

sustained component. However, irrespective of which current type contributes to residual current at $-20 \mathrm{mV}$, the distinction between the transient and sustained component in terms of sensitivity to a depolarizing conditioning pulse is clear. The current-voltage plot of peak inward currents under the 2 conditions indicates that currents above about $10 \mathrm{mV}$ are substantially unaffected by the depolarizing conditioning potential (Fig. 4D).

The second procedure for distinguishing between the 2 components is illustrated in Figure $4 C$. Addition of $5 \times 10^{-4} \mathrm{M}$ cadmium can be seen to result in a complete abolition of the sustained component of calcium current while blocking the transient component about $45 \%$ (measured at $-20 \mathrm{mV}$, where inward current is almost exclusively the transient component). Blockade of the transient current by cadmium seems somewhat more effective at more depolarized potentials $(+10$ and +30 $\mathrm{mV}$ ). The current-voltage curve of the residual inward current in cadmium closely overlaps the current-voltage curve of the current inactivated by the depolarizing conditioning potential (Fig. $4 D$ ). Together these 2 lines of evidence strongly indicate the presence of at least 2 components of calcium current in these cells rather than simply the complex kinetic behavior of a single class of calcium channel.

\section{Properties of outward currents}

Outward currents typically exhibited a transient shoulder decaying to a sustained current (Figs. 2, 5). In the presence of calcium, the rising phase of outward current was clearly contaminated by the presence of inward currents, and it is cxpected that steady-state currents are similarly affected. A major portion of outward current could be removed by perfusion with either 0 calcium saline or $30 \mathrm{~mm}$ TEA. In particular, most of the sustained outward current was abolished similarly by these treatments and the effect of simultaneous application of 0 calcium and TEA is shown in Figure $5 B$. Sensitivity to both calcium and TEA is indicative of the widely distributed large conductance calcium- and voltage-activated potassium channel (Adams et al., 1982; Dufy and Barker, 1982; Marty, 1981; Wong et al., 1982). As described below, we were able to verify the presence of a calcium- and voltage-sensitive potassium channel in identified lactotrophs using single-channel recording procedures (Fig. 7).

The residual outward current following removal of the calcium- and TEA-sensitive components could be further separated into 2 components through the use of depolarizing conditioning potentials. In Figure $5 B$, the cell was held at $-40 \mathrm{mV}$ for over $500 \mathrm{msec}$ in order to inactivate the transient component of outward current. Following such inactivation, a slowly activating sustained outward current remains. The overlap of the voltage-dependence of activation of the transient component with the sustained component complicates the analysis of the transient component. In order to observe the time course of the transient current and its inactivation properties in isolation, the transient component was first completely inactivated by a depolarizing step to $+40 \mathrm{mV}$. Subsequently, by stepping the cell to various more negative potentials for $100 \mathrm{msec}$ and then returning to $+40 \mathrm{mV}$, differing amounts of transient current were removed from inactivation (Fig. 6A). The sustained component of current activated in the absence of any transient current was then subtracted from the transient component (Fig. 6B). The peak activation of the transient component can be seen to occur within about 5-15 msec and inactivation occurs over about 50 $150 \mathrm{mscc}$. The removal of inactivation by $100 \mathrm{msec}$ steps to hyperpolarized potentials is shown in Figure $6 C$. This voltagedependence closely parallels that of the " $A$ " current found in many molluscan (Connor and Stevens, 1971) and vertebrate neurons (Adams et al., 1982; Freschi, 1983; Galvan and Sedl- 
A
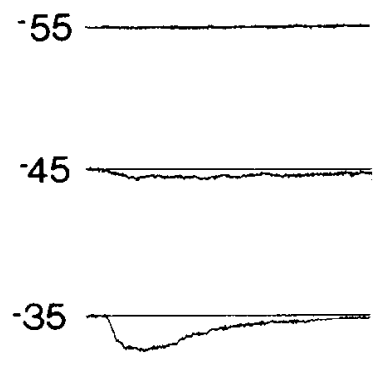

Figure 3. Inward calcium currents of identified lactotrophs. $A$, Lactotroph membrane current activated by a step from a holding potential of -80 $\mathrm{mV}$ to the indicated potentials. The pipette solution contained $130 \mathrm{~mm}$ $\mathrm{CsCl} ; 10 \mathrm{~mm}$ EGTA, $10 \mathrm{~mm} \mathrm{Na}-$ HEPES. The bath solution contained $140 \mathrm{~mm}$ 'l'ris-Cl, $10 \mathrm{~mm} \mathrm{CaCl}_{2} ; 500$ nм TTX, pH 7.2. Leakage and capacitative currents were subtracted digitally. Calibration bars: horizontal, $50 \mathrm{msec}$; vertical, $50 \mathrm{pA}$. B, Peak (filled circles) and sustained (open circles) inward current measured from the cell illustrated in $A$. Sustained current was measured at $150 \mathrm{msec}$ after initiation of the voltage command. Sustained current can be seen to vary with voltage independently of peak current.
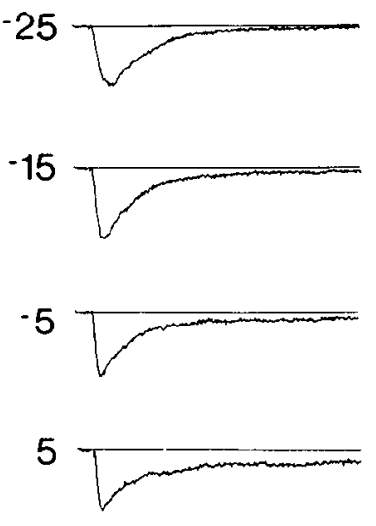

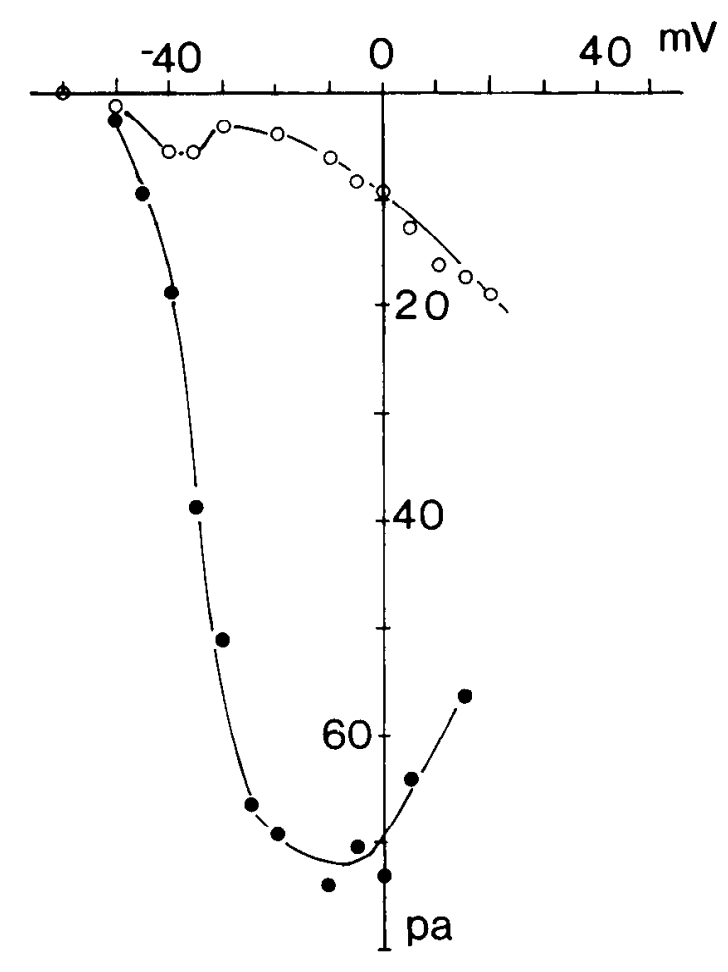

B meir, 1984). However, activation of this current in identified lactoirophs requires depolarizing steps to $-30 \mathrm{mV}$ and above, an activation curve that is shifted substantially relative to " $A$ " currents found in many other cells (Connor and Stevens, 1971; Freschi, 1983; Galvan and Sedlmeir, 1984). Since these other studies have used standard microelectrode voltage-clamp procedures, it is possible that the whole-cell recording mode results in a shift in the activation properties of this current, as is observed for sodium currents (e.g., Fenwick et al., 1982; Fernandez et al., 1984). As yet, no pharmacological tests of this component have been done.

A third component of potassium current clearly persists following removal of both calcium-activated outward currents and the transient current. Some of the basic properties of this current can be discerned in Figures 5 and 6 . The current activates relatively slowly even at potentials above $0 \mathrm{mV}$ (Fig. 5). In Figure $6 \mathrm{~A}$, currents corresponding to the turning off of this current can be seen during steps to the hyperpolarized command potentials. The current reverses between -70 and $-80 \mathrm{mV}$, and the deactivation of the current is faster at more negative potentials (Fig. $6 A$ ). The slow deactivation of this current suggests that it represents neither an unblocked component of the large-conductance calcium- and voltage-activated potassium current or a delayed rectifier current, since in other vertebrate cells the latter currents typically completely turn off within less than $40 \mathrm{msec}$ at potentials more negative than $-40 \mathrm{mV}$ (Adams et al., 1981). This current appears to make a relatively small contribution to total lactotroph outward currents.

\section{Putative single-channel correlates of whole-cell outward} currents

Cell-attached patch recordings were used to survey the types of single-channel events that might underly the outward current components described above. Three primary types of outward current were observed with patch recordings.

The large-conductance calcium- and voltage-activated potassium channel could be most clearly observed in excised patches of membrane (Fig. 7). The conductance of the channel was about $220 \mathrm{pS}$ with symmetrical potassium solutions. The currentvoltage relation of this channel was markedly nonlinear, in normal physiological ionic gradients with a slope of $\sim 120 \mathrm{pS}$ at around $100 \mathrm{mV}$ positive to the calculated potassium rcversal potential. The probability that the channel was open was increased either by membrane depolarization (Fig. 7) or by increases in the calcium concentration at the intracellular face of the membrane. Cell-attached recordings only rarely revealed the presence of this channcl cven at large depolarizations, although in many cases large spikelike events indicative of unresolved openings of this channel were observed.

To detect currents that might correspond to the transient component of whole-cell current, the pipette potential was repcatedly stepped to a specific negative (pipette voltage) command potential following a positive (pipette voltage) conditioning potential. The conditioning potential was typically $+40 \mathrm{mV}$ (pipette voltage). For 6 patches examined, a net transient current could be observed following pipette command potentials to at 


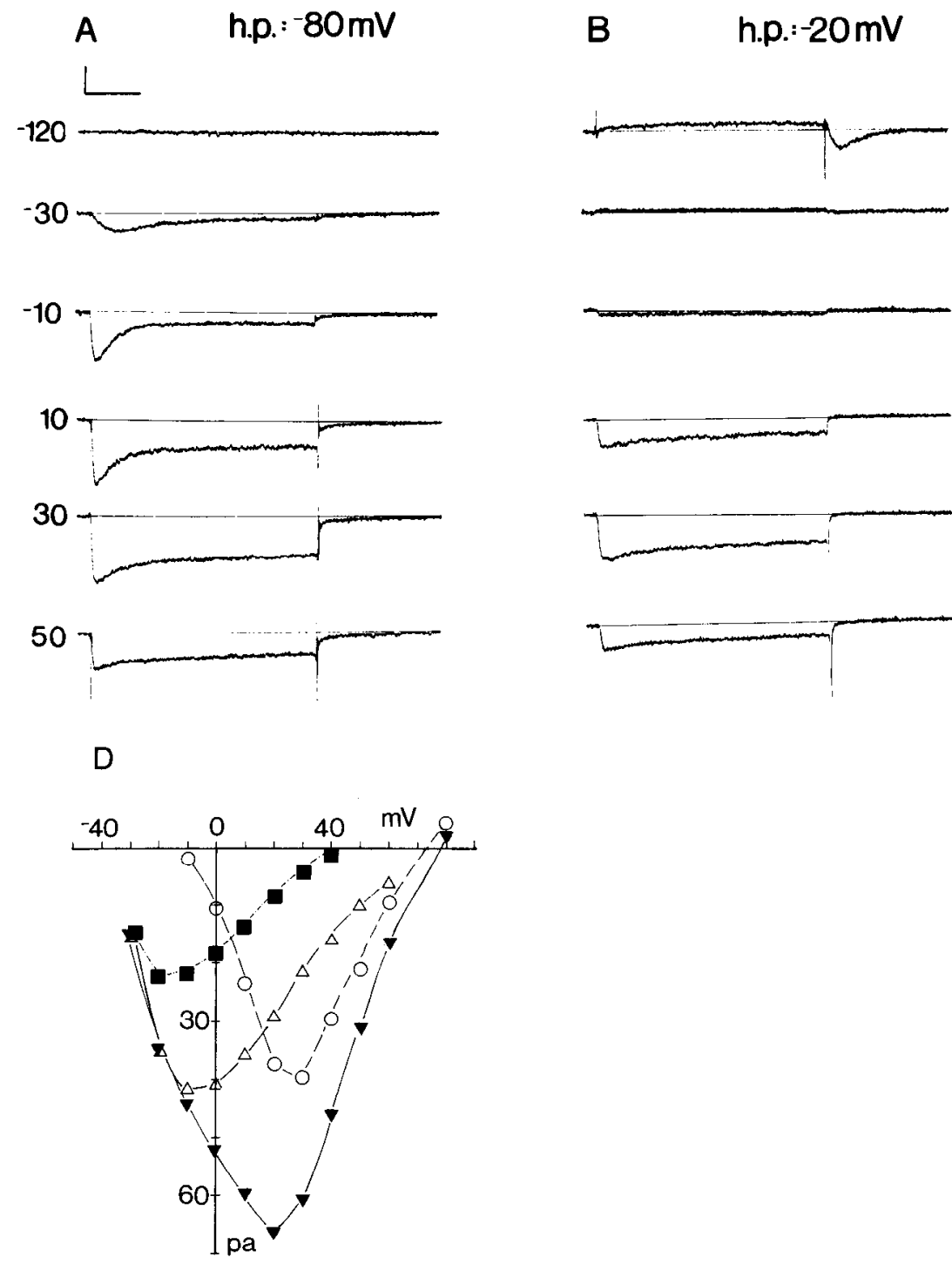

C h.p. $-80 \mathrm{mV}+0.5 \mathrm{mMCd}^{+*}$

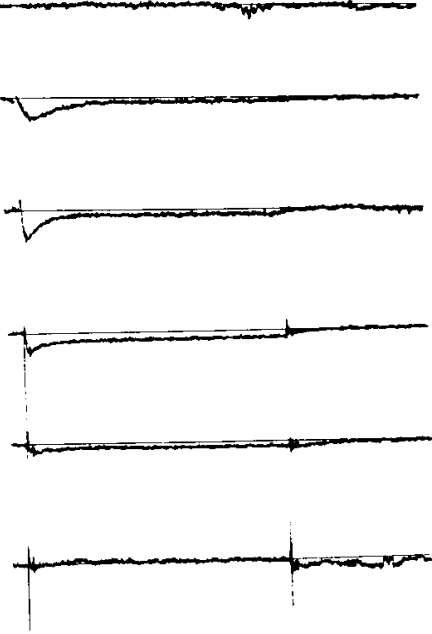

Figure 4. Qualitative separation of 2 components of calcium current. Pipette and bath solutions were as in Figure 3. A, Currents activated by steps from a holding potential of $-80 \mathrm{mV}$ to the indicated cell potentials. Following the command potential, the potential was returned to the indicated holding potential. $B$, Currents activated at the indicated potentials following a $500 \mathrm{msec}$ interval at $-20 \mathrm{mV}$. Following the command potential, the potential was returned to the indicated holding potential. Cells were held at $-80 \mathrm{mV}$ for 500 msec between pulse sequences. $C$, Currents were activated at the indicated potentials from a holding potential of $-80 \mathrm{mV}$ but in the presence of $0.5 \mathrm{~mm} \mathrm{CdCl}$. Calibration bars: horizontal, $50 \mathrm{msec}$; vertical, $25 \mathrm{pA}$. D. Peak inward current is plotted versus cell command potentials under various conditions. Filled triangles indicate peak currents activated from a holding potential of $-80 \mathrm{mV}$; open circles, currents from a holding potential of $-20 \mathrm{mV}$; open triangles, difference current reflecting that component of peak current removed by the depolarizing conditioning pulse; filled squares, peak current activated from a holding potential of $-80 \mathrm{mV}$ that persists in the presence of $0.5 \mathrm{mM} \mathrm{CdCl}$.

least $-20 \mathrm{mV}$ (Fig. $8 A$ ). In the absence of a positive conditioning potential (pipette voltage), such transient currents were reduced or absent. This current increased in amplitude as a function of the command potential (Fig. 8A). Although in some cases individual steps of opening and closing transitions of single channels could be discerned, typically transient currents appeared to reflect the relatively coincident activation and inactivation of a large number of channels. Coupled with the simultaneous activation of inward currents in such patches, any attempt to clearly resolve elementary current transitions was precluded. Activation of such transient currents was never observed at the cell resting potential, even with pipette conditioning potentials of $+80 \mathrm{mV}$.

Averages of a large number of single sweeps are shown in Figure $8 B$. The time course of activation of transient current measured under cell-attached recordings closely parallels that of the activation of transient current observed in whole-cell recordings. Although the time course of inactivation of transient current observed in Figure $8 B$ is substantially faster than observed in whole-cell recordings (Fig. $7 B$ ), there was considerable variability in the rate of inactivation of transient currents measured in the cell-attached mode.

During prolonged commands $(2-30 \mathrm{sec})$ to negative pipette potentials, a third type of outward channel was observed in cellattached patches (Fig. $8 C$ ). This channel had a conductance of about 12-20 pS measured over pipette potentials of -40 to $-100 \mathrm{mV}$. Some rectification in the single-channel current amplitude was observed at pipette potentials more negative than $-80 \mathrm{mV}$. This channel occurred in bursts of openings that were prolonged with effective membrane depolarizations. Over 10$20 \mathrm{sec}$, the channel exhibited a slow inactivation. As seen in Figure $8 A$, openings of this channel could be discerned following 
A
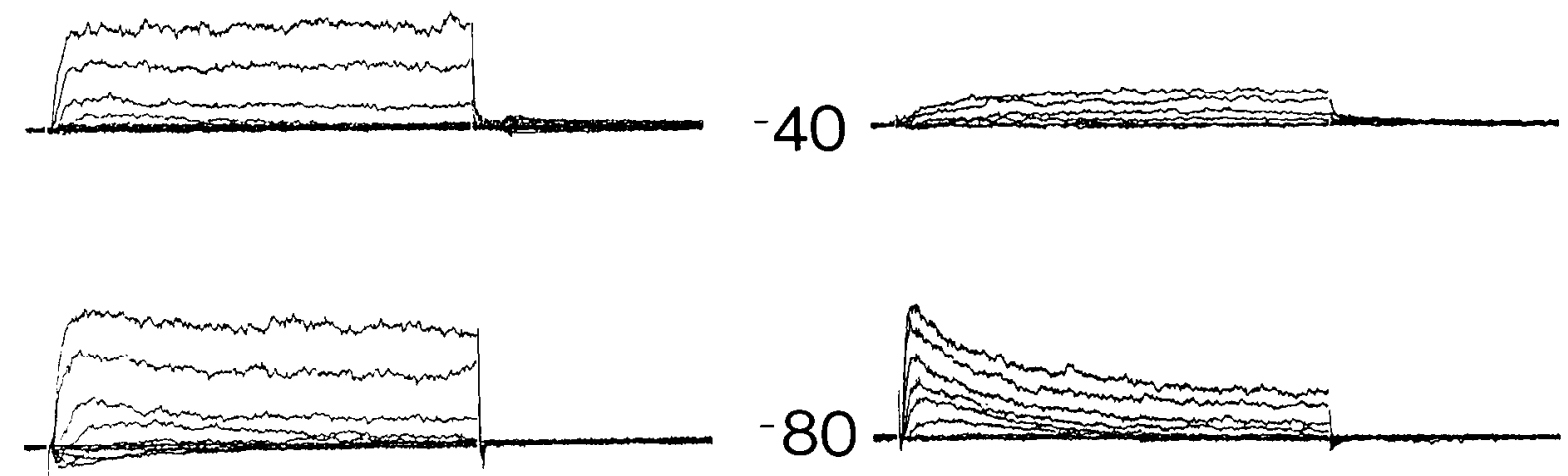

Figure 5. Outward currents of identified lactotrophs. Representative families of outward currents obtained from the indicated holding potentials $(-40$ and $-80 \mathrm{mV})$ are illustrated. $A$, Currents in normal physiological ionic gradients. $B$, Currents obtained after superfusion with saline containing $30 \mathrm{~mm}$ TEA and 0 calcium. Command steps were to -50 through $20 \mathrm{mV}$ in steps of $10 \mathrm{mV}$. Cells were held at the precommand potential for 500 msec. Another $500 \mathrm{msec}$ interval at $-80 \mathrm{mV}$ separated each pulse sequence. In normal saline, a transient component of outward current is observed at small depolarizations. With 0 calcium, $30 \mathrm{~mm}$ TEA, there is a large reduction in the sustained component of outward current. Top right, current remaining following inactivation of the transient current is illustrated. Calibration bars: horizontal, $50 \mathrm{msec}$; vertical, $100 \mathrm{pA}$.

inactivation of the transient current. However, the ensemble averages of Figure $8 B$ indicate that the contribution of this channel to total whole-cell current is probably small and, as yet, we have no information on the activation of this channel from ensemble averages.

We were concerned that this relatively sustained channel might simply reflect the occasional recovery from inactivation and reopening of the channel responsible for the transient current component. This is unlikely, since the lifetimes of bursts of openings of the late channels are substantially longer than the inactivation rate of the transient channel. To account for this difference, the late channels must represent either a separate type of channel distinct from the transient current or a uniquely different kinetic mode of behavior of the transient channel.
Figure 6. Isolation of transient outward current. $A$, Cell was held at +40 $\mathrm{mV}$ for over $500 \mathrm{msec}$, and the potential was then stepped to different negative command potentials before returning to $+40 \mathrm{mV}$. Saline contained $30 \mathrm{~mm}$ TEA, 0 calcium. Command steps were to $-120 \mathrm{mV}$ and -100 through $-20 \mathrm{mV}$ in steps of 10 $\mathrm{mV}$. Slow tail component reverses between -70 and $-80 \mathrm{mV}$. $B$, Current during a trace in $A$ in which no transient current was activated was subtracted from all other traces to illustrate the time course of activation and inactivation of transient outward currents in isolation. Transient currents reach a peak in less than $10 \mathrm{msec}$ and inactivate over $50-150 \mathrm{msec}$. $C$, For a $100 \mathrm{msec}$ command potentials, only potentials more negative than -60 $\mathrm{mV}$ were sufficient to produce removal of inactivation of the transient current component. Calibration bars: horizontal, $50 \mathrm{msec}$; vertical, $50 \mathrm{pA}$.

\section{A}
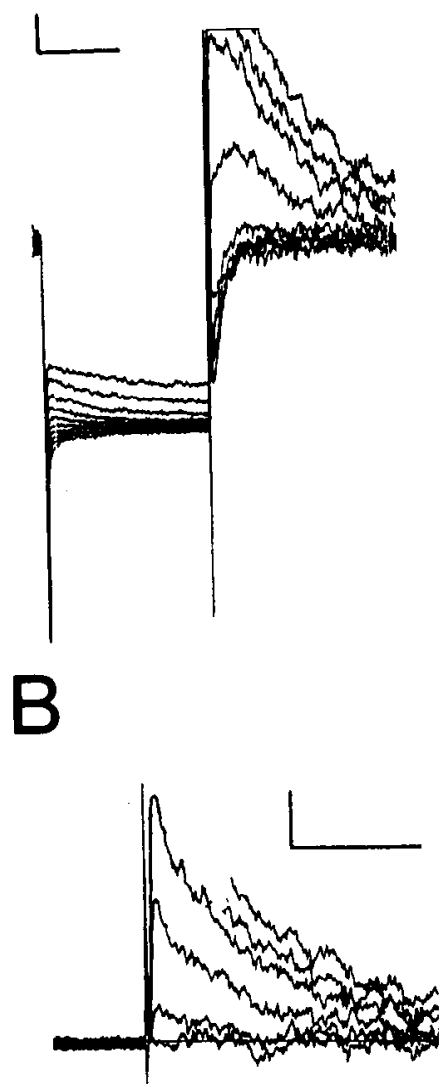
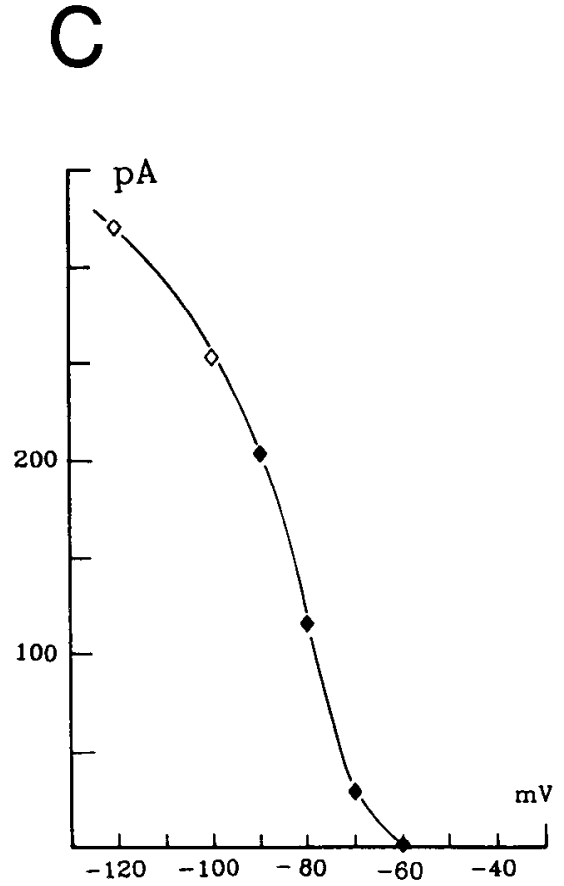


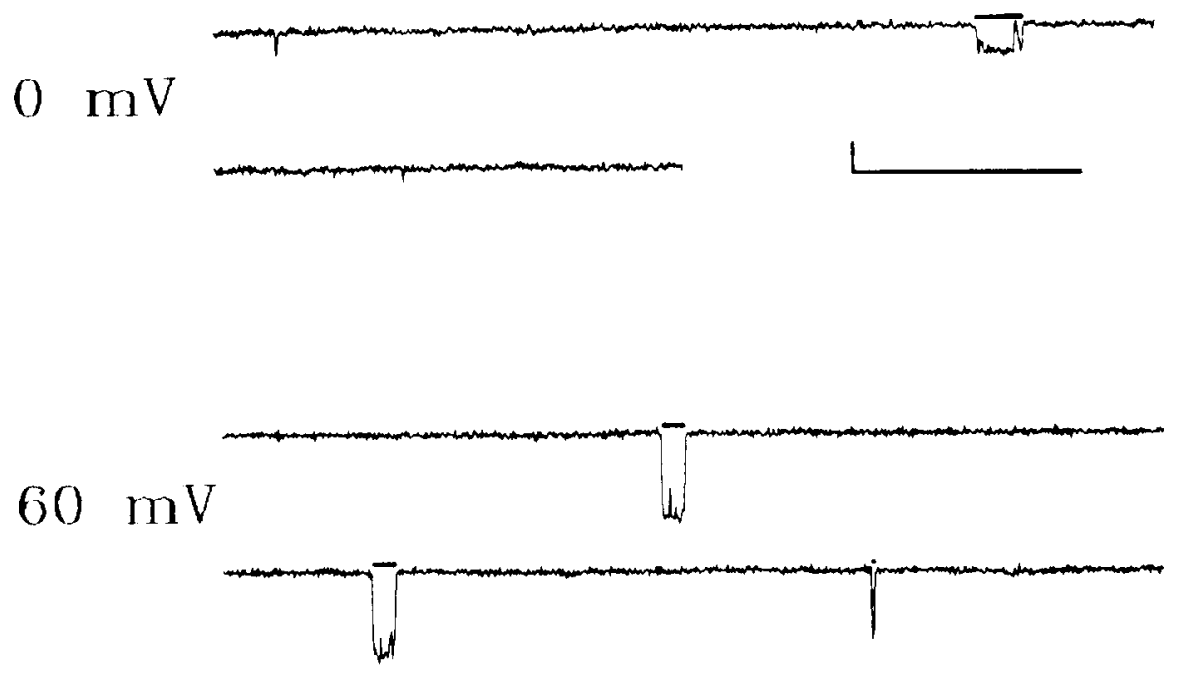

Figure 7. Large-conductance calcium- and voltage-activated potassium channel. Currents from an excised outside-out patch containing a large-conductance voltage- and calcium-activated potassium channel are illustrated. Pipette solution contained less than $10^{-8} \mathrm{M}$ calcium $(140 \mathrm{~mm}$ $\mathrm{KCl}, 0$ mm calcium, 5 mm EGTA, 10 mM KHEPES), and bath solution contained the normal physiological saline. Potentials indicate pipette command voltage. Horizontal bars indicate single-channel events. Calibration bars: horizontal, $25 \mathrm{msec}$; vertical, $6 \mathrm{pA}$.

\section{Discussion}

We have used the reverse hemolytic plaque assay to begin a study of the electrophysiological properties of specific identified subtypes of cells found in heterogeneous anterior pituitary cell cultures. The results present a qualitative description of some of the primary electrical properties and membrane currents found in the prolactin-secreting lactotrophs.

The ultimate aim of these experiments is the characterization of cellular mechanisms underlying control of prolactin secretion. Although more detailed analysis of the currents in lactotrophs is clearly required, the present results provide an initial description of some of the major currents found in these cells. It is of interest to compare the present results to work obtained on clonal lines of pituitary cells that have provided a prime model of pituitary cell function.

The existence of at least 2 components of calcium current in normal lactotrophs is similar to observations on GH3 cells by Armstrong and Matteson (1985) who discerned 2 components on the basis of calcium tail currents. In previous work that failed to observe multiple calcium current components, no specific attempt to resolve multiple components was made (Dubinsky and Oxford, 1984; Hagiwara and Ohmori, 1982; Matteson and Armstrong, 1984). The existence of multiple components of calcium current in a variety of cell types is now well established (Armstrong and Matteson, 1985; Carbone and Lux, 1984; Nowycky et al, 1985). The properties of the 2 components of lactotroph calcium current observed here appear to be similar to 2 components of calcium current found in the GH3 pituitary cell line (Armstrong and Matteson, 1985), and they appear to correspond to 2 of the 3 components of calcium current found in dorsal root ganglion neurons (Nowycky et al., 1985).
Several facets of the currents in identified lactotrophs are worthy of comment in terms of the control of hormone release. First, in comparison to work on $\mathrm{GH} 3$ cells, the magnitude of peak calcium currents in normal lactotrophs from ovariectomized rats appears reduced, and the absence of spontaneous action potentials contrasts with many GH3 cells (Dubinsky and Oxford, 1984). Additionally, in contrast to studies on clonal cells (Armstrong and Matteson, 1985; Hagiwara and Ohmori, 1982), the transient component of calcium current appears more prominent in the cells examined by us. It is now clear that the sustained component of calcium current in many cells is labile (e.g., Byerly and Hagiwara, 1982; Nowycky et al., 1985) and sensitive to regulation by diffusible intracellular factors. The possibility that various components of total whole-cell calcium current could be regulated in accordance with physiological conditions (Fukushima et al., 1984) would have dramatic consequences for the regulation of hormone secretion, and this possibility is currently being investigated. Finally, the differential voltage dependence of the 2 currents suggests that each component may have different physiological roles on particular aspects of the secretion of hormone, e.g., basal versus secretagogue-evoked release.

The calcium-sensitive outward current and transient outward current observed in normal lactotrophs are also similar to 2 current components described in clonal lines of pituitary cells (Dubinsky and Oxford, 1984). In this latter study, the transient current is described as an inactivating delayed rectifier current. At present we feel that, despite the shift in the voltage dependence of the activation of this current, the transient current is probably in " $A$ " current. Recently, the transient current in GH3 cells has been shown to be sensitive to 4-aminopyridine (May and Oxford, 1986). Our results also indicate the presence of a 

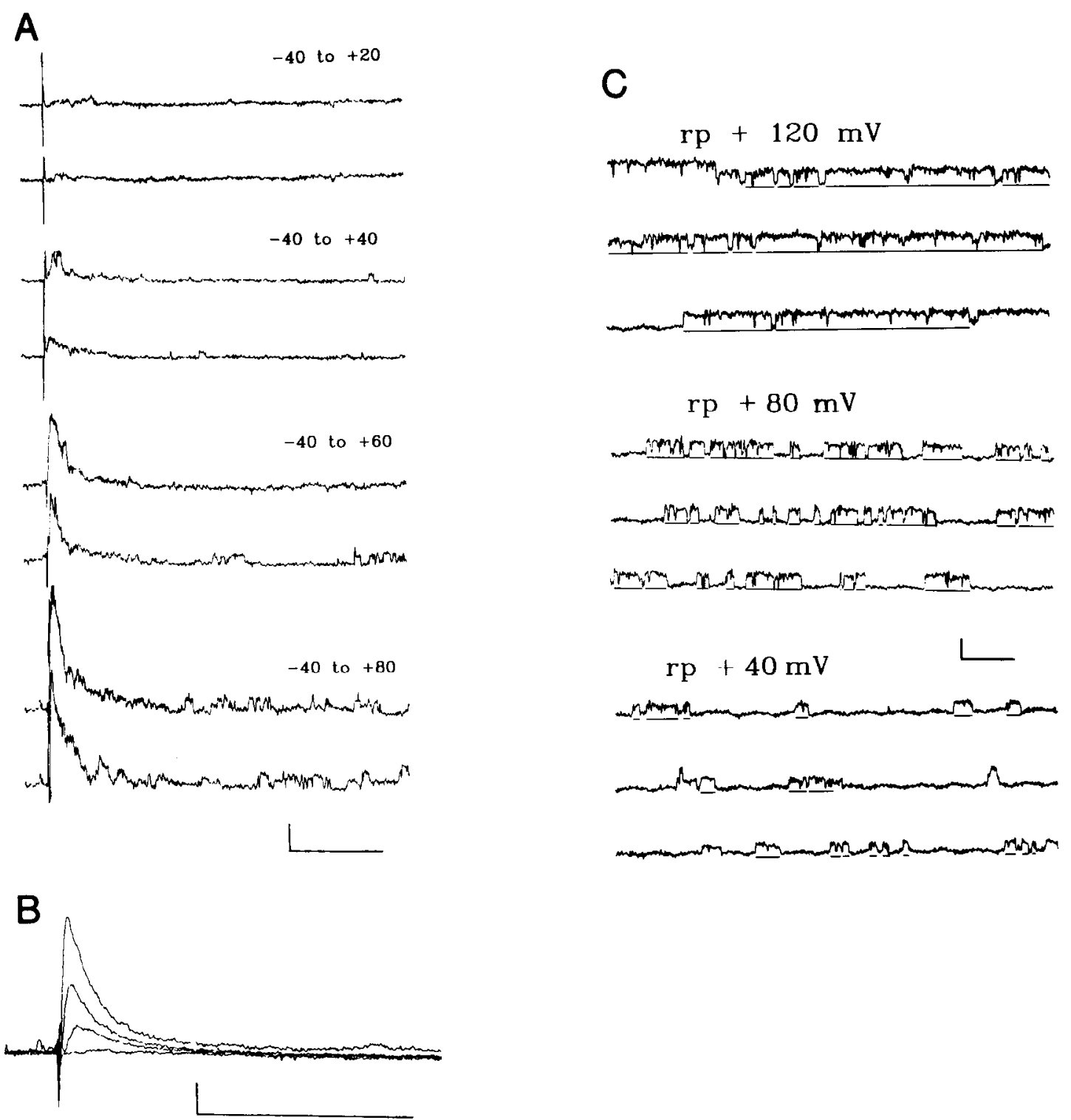

Figure 8. Outward currents in cell-attached patches. $A$, In cell-attached patches, transient outward currents were activated by depolarizing voltage steps (pipette inside negative) following hyperpolarizing conditioning potentials (pipette inside positive). Potentials indicate effective transmembrane potential to be added to the cell resting potentials. $B$, Averages of 40 sweeps to the potentials indicated in $A$. Calibration bars for both $A$ and $B$ : horizontal, $75 \mathrm{msec}$; vertical, $5 \mathrm{pA}$. $C$, Outward channels observed during sustained depolarizing voltage commands to the indicated transmembrane potentials. Single-channel current amplitudes at the indicated voltages were $1.1 \mathrm{pA}$ at resting potential $(r p)+40 \mathrm{mV}, 1.55 \mathrm{at} \mathrm{rp}+80 \mathrm{mV}$, and 1.7 $\mathrm{pA}$ at $\mathrm{rp}+120 \mathrm{mV}$. Rectification in the single-channel current amplitude at potentials above $\mathrm{rp}+80 \mathrm{mV}$ was consistently observed. Calibration bars: horizontal, $25 \mathrm{msec}$; vertical, $3 \mathrm{pA}$.

slowly activating third component of potassium current. In addition, the 3 primary currents observed with cell-attached patches appear to correspond quite well with the 3 components of wholecell outward current. However, the minimal tests presented here cannot rigorously rule out additional components, and, in fact, an apamin-sensitive, calcium-activated, TEA-resistant potassium current has been described in GH3 cells (Ritchie, 1985). In some patch recordings we have also observed at least 2 other outward single channels that appear unrelated to any of the whole-cell currents described here. Similar to neuronal prcparations (Adams et al., 1981; Galvan and Sedlmeir, 1984), the normal lactotroph appears to exhibit a rich variety of outward currents available for regulation by agents that might modify the secretory process. The ability of releasing factors to alter potassium currents in clonal pituitary cells has, in fact, been demonstrated (Dufy and Barker, 1983; Dubinsky and Oxford, 1985).
Some previous electrophysiological studies of normal pituitary cells have used regions of pituitary tissues thought to be enriched in particular subtypes of secretory cells (Mason and Waring, 1985; Taraskevitch and Douglas, 1978) or, alternatively, used cells without regard to specific cell identify (Taraskevitch and Douglas, 1977). As yet, little information on specific membrane currents in normal pituitary cells is available, although the existence of calcium currents is implied by the occurrence of calcium-dependent action potentials (Mason and Waring, 1985; Taraskevitch and Douglas, 1977). Ultimately, it will be of interest to understand the similarities and differences among subtypes of pituitary cells. In a limited number of experiments, we have examined some cells around which plaques failed to occur. Such cells exhibited outward currents qualitatively similar to those seen with lactotrophs, although the magnitude of sustained outward currents appears greater. Also, it is likely that the occurrence of 2 components of calcium current 
may be a general feature of different secretory cell subtypes (Marchetti et al., 1986). Similarity in the basic types of currents found in different subtypes of cells would not be too surprising. However, the mechanisms by which different currents may be regulated by inhibitors or promoters of hormone release are likely to be quite specific to different cell subtypes. As such, the use of the plaque assay as a means for unambiguous cell identification will be particularly important in subsequent studies of the action of modifiers of hormone release.

This paper has shown that the reverse hemolytic plaque assay is a simple and useful tool for the routine identification of lactotrophs of the anterior pituitary in dispersed heterogeneous cell cultures under conditions suitable for subsequent patch-clamp electrophysiology. The plaque assay has also been applied to other pituitary cell subtypes (Smith et al., 1984). The general usefulness of the method for other dispersed heterogeneous cell populations remains to be demonstrated. The presence of specific peptides in association with particular neuronal subpopulations suggests that this approach will also have promise for the electrophysiological characterization of specific neuronal subtypes within heterogeneous populations.

\section{References}

Adams, P. R., D. A. Brown, and A. Constanti (1981) M-currents and other potassium channels in bullfrog sympathetic neurons. J. Physiol. (Lond.) 33: 537-572.

Adams, P. R., A. Constanti, D. A. Brown, and R. B. Clark (1982) Intracellular $\mathrm{Ca}^{2+}$ activates a fast voltage-sensitive $\mathrm{K}^{+}$current in vertebrate sympathetic neurones. Nature 296: 746-749.

Adler, M., B. S. Wong, S. L. Sabol, N. Busis, M. B. Jackson, and F. F. Weight (1983) Action potentials and membrane ionic channels in clonal anterior pituitary cells. Proc. Natl. Acad. Sci. USA 80: 20862090.

Armstrong, C. M., and D. R. Matteson (1985) Two distinct populations of calcium channels in a clonal line of pituitary cells. Science 227: $65-67$

Biales, B., M. A. Dichter, and A. Tischler (1977) Sodium and calcium action potentials in pituitary cells. Nature $267: 172-174$.

Byerly, L., and S. Hagiwara (1982) Calcium currents in internally perfused nerve cell bodies of Limnea stagnalis. J. Physiol. (Lond.) 322: 503-528.

Carbone, E., and H. D. Lux (1984) A low voltage-activated calcium conductance in embryonic chick sensory neurons. Biophys. J. 46: 413-418.

Conner, J. A., and C. F. Stevens (1971) Voltage clamp studies of a transient outward membrane current in gastropod neural somata. J. Physiol. (Lond.) 213: 21-30.

Cunningham, A. J., and A. Szenberg (1968) Further improvements in the plaque technique for detecting single antibody-forming cells. Immunology 14: 599-600.

Denef, C., E. Hautekeete, and R. Dewals (1978) Monolayer cultures of gonadotrophs separated by velocity sedimentation: Heterogeneity in response to luteinizing hormone-releasing hormone. Endocrinology 103: 736 .

Dubinsky, J. M., and G. S. Oxford (1984) Ionic currents in two strains of rat anterior pituitary tumor cells. J. Gen. Physiol. 83: 309-339.

Dubinsky, J. M., and G. S. Oxford (1985) Dual modulation of K channels by thyrotropin-releasing hormone in clonal pituitary cells. Proc. Natl. Acad. Sci. USA 82: 4282-4286.

Dufy, B., and J. L. Barker (1982) Calcium-activated and voltagedependent potassium conductances in clonal pituitary cells. Life Sci. 30: 1933-194i.

Dufy, B., and J. L. Barker (1983) Transient outward currents in clonal pituitary cells are regulated by peptide hormones. Soc. Neurosci. Abstr. 9: 711 .

Fenwick, E. M., A. Marty, and E. Neher (1982) Sodium and calcium channels in bovine chromaffin cells. J. Physiol. (Lond.) 331: 599635.

Fernandez, J. M., A. P. Fox, and S. Krasne (1984) Membrane patches and whole-cell membranes: A comparison of electrical properties in rat colonal pituitary $\left(\mathrm{GH}_{3}\right)$ cells. J. Physiol. (Lond.) 356: 565-585.

Freschi, J. E. (1983) Membrane currents of cultured rat sympathetic neurons under voltage clamp. J. Neurophysiol. 50: 1460-1478.

Fukushima, T., S. Hagiwara, and R. E. Saxton (1984) Variation of calcium current during the cell growth cycle in mouse hybridoma lines secreting immunoglobulins. J. Physiol. (Lond.) 355: 313-321.

Galvan, M., and C. Sedlmeir (1984) Outward currents in voltageclamped rat sympathetic neurones. J. Physiol. (Lond.) 356:115-133

Gorospe, W. C. and M. E. Freeman (1984) Uterus of the rat contains prolactin inhibitory activity. Am. J. Physiol. 247: E251-E257.

Hagiwara, S., and H. Ohmori (1982) Studies of calcium channels in clonal pituitary cells with patch electrode voltage clamp. J. Physiol. (Lond.) 331: 213-252.

Hagiwara, S., K. Kusano, and N. Saito (1961) Membrane changes of Onchidium nerve cell in potassium-rich media. J. Physiol. (Lond.) 155: 470-489.

Hamill, O. P., A. Marty, E. Neher, B. Sakmann, and F. J. Sigworth (1981) Improved patch clamp techniques for high-resolution current recording from cells and cell-free membrane patches. Pfluegers Arch. 391: 85-100.

Jerne, N. K., C. Henry, A. A. Nordin, H. Fuji, A. M. C. Koros, and I. I efkovits (1974) Plaque forming cells: Methodology and theory. Transplant. Rev. 18: 130-191.

Kidokoro, T. (1975) Spontaneous calcium action potentials in a clonal pituitary cell line and their relationship to prolactin secretion. Nature 258: 741-742.

Leong, D. A., L. S. Frawley, and J. D. Neill (1983) Neuroendocrine control of prolactin secretion. Annu. Rev. Physiol. 45: 109-127.

Lingle, C. J., S. Sombati, M. Truman, and M. E. Freeman (1985a) Outward currents of identified lactotrophs in cultures of dispersed rat anterior pituitary. Biophys. J. 47: 136a.

Lingle, C. J., S. Sombati, M. Truman, and M. E. Freeman (1985b) Properties of whole-cell calcium and potassium currents in identified lactotrophs from dissociated rat anterior pituitary. Soc. Neurosci. Abstr. 11:359.

Marchetti, C. F., G. V. Childs, and A. M. Brown (1986) The calcium currents of anterior pituitary cells. Biophys. J. 49: 176a.

Marty, A. (1981) Ca-dependent $\mathrm{K}^{+}$channels with large unitary conductance in chromaffin cell membranes. Nature 291: 497-500.

Mason, W. T., and D. W. Waring (1985) Electrophysiological recordings from gonadotrophs. Neuroendocrinology 41: 258-268.

Matteson, D. R., and C. M. Armstrong (1984) Na and Ca channels in a transformed line of anterior pituitary cells. J. Gen. Physiol. 83: 371-394.

May, K. W., and G. S. Oxford (1986) Pharmacological isolation and characterization of a voltage-dependent $\mathrm{K}$ channel in $\mathrm{GH} 3$ cells. Biophys. J. 49: 164a.

Molinaro, G. A., W. C. Eby, and C. A. Molinaro (1981) The reverse plaque-forming cell assay. Methods Enzymol. 73: 326-338.

Neill, J. D., and L. S. Frawley (1983) Detection of hormone release from individual cells in mixed populations using a reverse hemolytic plaque assay. Endocrinology 112: 1135-1137.

Neill, J. D., and L. E. Reichert (1971) Development of a radioimmunoassay for rat prolactin and evaluation of the NIAMDD rat prolactin radioimmunoassay. Endocrinology 88: 548-555.

Nowycky, M. C., A. P. Fox, and R. W. Tsien (1985) Three types of neuronal calcium channel with different calcium agonist sensitivity. Nature 316: 440-443.

Ritchie, A. K. (1985) Two pharmacologically distinct $\mathrm{Ca}^{++}$-activated $\mathrm{K}^{+}$currents are present in the GH3 anterior pituitary cell line. Soc. Neurosci. Abstr. 11: 954.

Smith, P. F., L. S. Frawley, and J. D. Neill (1984) Detection of LH release from individual pituitary cells by the reverse hemolytic plaque assay: Estrogen increases the fraction of gonadotrophs responding to GnRH. Endocrinology 115: 2484-2486.

Taraskevitch, P.S., and W. W. Douglas (1977) Action potentials occur in cells of normal anterior pituitary gland and are stimulated by the hypophysiotropic polypeptide thyrotropin releasing hormone. Proc. Natl. Acad. Sci. USA 74: 4064-4067.

Taraskevitch, P. S., and W. W. Douglas (1978) Catecholamines of supposed inhibitory hypophysiotrophic function suppress action potentials in prolactin cells. Nature 276: 832-834.

Vale, W., G. Grant, M. Amoss, R. Blackwell, and R. Guillemin (1972) Culture of enzymatically dispersed anterior pituitary cells: Functional validation of a method. Endocrinology 91: 562-572.

Wong, B. S., H. Lecar, and M. Adler (1982) Single calcium-dependent potassium channels in clonal anterior pituitary cells. Biophys. J. 39: 313-317. 